\title{
ЗАДОВОЛЕННЯ ПРОФЕСІЙНОЮ ДІЯЛЬНІСТЮ ЯК ПОКАЗНИК САМОРЕАЛІЗАЦІЇ МЕДИЧНИХ СЕСТЕР
}

Задоволення профресійною діяльністю як показник самореалізації медичних сестер

\section{М. І. Марущак, Х. Я. Максів}

Тернопільський національний медичний університет імені І. Я. Горбачевського МОЗ України

Резюме. Готовність до профресійної самореалізації, що передбачає максимальне задовлення від профресійної діяльності, на думку дослідників, включає багато комонентів.

Мета дослідження - проаналізувати компоненти профресійної діяльності медичних сестер та їх задоволення відповідно до тривалості їх праці.

Матеріали і методи. В анкетуванні взяла участь 61 медична сестра. Респондентів поділили на 4 групи відповідно до тривалості роботи: перша - стаж роботи до 5 років, друга - стаж роботи 6-10 років, третя група - стаж роботи 11-20 років, четверта - стаж роботи понад 20 років. Вимірювали важливість роботи та задоволення працею, що базується на теорії мотивації Ф. Герцберга, та адаптована для маркетингових досліджень лікувально-профілактичних закладів.

Результати. Серед основних мотиваторів трудової діяльності (виконувати цікаву роботу; досягати особистих цілей під час роботи; мати можливість профресійного росту; одержувати заробітну платню відповідно до обсягу та якості роботи; брати участь і відчувати значущість своєї роботи в досягненні результатів діяльності лікувально-профрілактичного закладу; брати участь в ухваленні рішень із проблем медичного обслуговування) медсестри, незалежно від стажу, найважливішим вважають одержання достойної заробітної плати відповідно до обсягу та якості виконаної роботи. Серед інших важливих компонентів медичні сестри усіх дослідних груп виділяють комфрортні умови праці та добрі стосунки з колегами.

Висновки. Найбільшою мірою задоволення середнього медичного персоналу професійною діяльністю пов'язане зі здатністю себе почувати частиною колективу, найменшою мірою - з оплатою праці.

Ключові слова: задоволення роботою; мотиватори; стаж роботи; медсестри.
Satisfaction with professional activity as an indicator of self-realization of nurses

M. I. Marushchak, H. Ya. Maksiv

I. Horbachevsky Ternopil National Medical University

e-mail: marushchak@tdmu.edu.ua

Summary. Readiness for professional self-realization, which provides maximum satisfaction from professional activities, according to researchers, includes many components.

The aim of the study - to analyze the components of the professional activity of nurses and their satisfaction in accordance with the duration of their work.

Materials and Methods. 61 nurses took part in the survey. Respondents were divided into 4 groups according to the duration of work: group 1 - work experience up to 5 years, group 2 - work experience 6-10 years, group 3 - work experience 11-20 years, group 4-work over 20 years. We measured the importance of work and job satisfaction, which is based on the theory of motivation of F. Herzberg and adapted for marketing research of treatment and prevention facilities.

Results. Among the main motivators of work (perform interesting work; achieve personal goals while working; have the opportunity for professional growth; receive a salary in accordance with the volume and quality of work; participate and feel the importance of their work in achieving the results of treatment and prevention; participate in decision-making on health care issues) nurses, regardless of length of service, consider it most important to receive a decent salary in accordance with the volume and quality of work performed. Among other important components, nurses from all research groups highlight comfortable working conditions and good relationships with colleagues.

Conclusions. To the greatest extent, the satisfaction of nurses with professional activities is associated with the ability to feel part of the team, to a lesser extent - with pay.

Key words: job satisfaction; motivators; work experience; nurses. 


\section{ВСТУП}

Готовність до професійної самореалізації, що передбачає максимальне задовлення від професійної діяльності, на думку дослідників, включає багато комонентів: ціннісно-мотиваційний компонент (стійка професійна мотивація, орієнтація на цінність самореалізації у професійній діяльності, відповідальність за свій подальший розвиток і життєвий шлях, інтелект, сумлінність, чесність, відповідальність, ініціативність, справедливість, надійність, рішучість); змістовний компонент (система професійних знань, а також знання про особисту саморегуляцію й оптимальні способи самоорганізації, необхідний набір професійних навичок і умінь, навичок саморегуляторної діяльності); процесуальний компонент (здатність до творчої ресрлексії й розуміння, самостійність мислення й дії, організаторські вміння, лідерський потенціал, уміння педагогічного спілкування); контролювально-вольовий компонент (самодисципліна, упевненість у собі, цілеспрямованість, наполегливість у досягненні цілей, самовладність, самоконтроль, здатність до самоосвіти, навчання) [1]. Як вважає К. Абульханова-Славська [2], задоволення $€$ об'єктивною й суб'єктивною результативною діяльністю особистості, яка підтримує ії̈ подальшу мотивацію за принципом зворотного зв'язку.

Метою дослідження було проаналізувати компоненти професійної діяльності медичних сестер та їх задоволення відповідно до тривалості їх праці.

\section{МАТЕРІАЛИ І МЕТОДИ}

В анкетуванні взяла участь 61 медична сестра. Респондентів поділили на 4 групи відповідно до тривалості роботи: перша - стаж роботи до 5 років (11 осіб), друга - стаж роботи 6-10 років (22 особи), третя група - стаж роботи 11-20 років (18 осіб), четверта - стааж роботи понад 20 років (10 осіб).

Найбільш поширеним методом оцінки професійної діяльності персоналу є вимірювання важливості роботи та задоволення працею, що базується на теорії мотивації Ф. Герцберга, та адаптований для маркетингових досліджень лікувально-профрілактичних закладів [3-5]. За даною теорією, дві групи чинників приводять до різних результатів: чинники мотивації - до задоволення своєю працею, тоді як гігієнічні чинники лише нівелюють незадоволення.

Анкета передбачала оцінку медичними сестрами наступних складових професійної діяльності:

1. Брати участь в ухваленні рішень із проблем медичного обслуговування (мотиватор).

2. Бути лідером у колективі.

3. Бути інфрормованим про результати своєї роботи.

4. Мати можливість одержувати нові знання й освоювати нові технології.
5. Одержувати об'єктивну оцінку своєї діяльності безпосереднім керівником.

6. Самостійно ухвалювати рішення в рамках своєї професійної компетенції.

7. Брати участь і відчувати значущість своєї роботи в досягненні результатів діяльності лПз (мотиватор).

8. Мати можливість кар'єрного росту.

9. Мати можливість професійного росту (мотиватор).

10. Виконувати цікаву роботу (мотиватор).

11. Досягати особистих цілей під час роботи (мотиватор).

12. Підтримувати добрі відносини з безпосереднім керівником.

13. Почувати себе частиною колективу.

14. Підтримувати добрі відносини з колегами.

15. Мати коморортні умови праці.

16. Одержувати заробітну платню відповідно до обсягу та якості роботи (мотиватор).

Оцінку результатів проводили за методикою двомірного аналізу «важливість-задоволення».

\section{РЕЗУЛЬТАТИ Й ОБГОВОРЕННЯ}

Серед 6 мотиваторів (виконувати цікаву роботу; досягати особистих цілей під час роботи; мати можливість профресійного росту; одержувати заробітну платню відповідно до обсягу та якості роботи; брати участь і відчувати значущість своєї роботи в досягненні результатів діяльності ЛП3; брати участь в ухваленні рішень із проблем медичного обслуговування) медсестри як загалом, так і окремо по групах, найважливішим вважають одержання гідної заробітної плати відповідно до обсягу та якості виконаної роботи. Даний мотиватор є домінуючим у дослідженнях інших науковців [3]. На державному рівні, за умов сучасної пандемії Covid-19, також прийнято рішення про збільшення заробітної плати медикам на 300 \%, що підтверджує вагомість даного мотиватора. Серед інших важливих компонентів-мотиваторів перша група відзначає виконання цікавої роботи (4 місце), тоді як друга група цей компонент ставить на 6 місце. Для медичних сестер зі стажем роботи 11-20 років важливішим мотиваторм є досягнення особистих цілей (5 місце), тоді як виконання цікавої роботи, згідно з отриманими результатами, відповідає 7 рангу. Медичні сестри зі стажем роботи понад 20 років відводять 8 і 9 місце відповідно до виконання цікавої роботи і досягнення особистих цілей (табл., рис. 1-5). Найменше медсестер турбують питання участі в ухваленні рішень з проблем медичного обслуговування.

Ще одним важливим мотиватором задоволення професійної діяльності медсестри вважається можливість професійного росту, проте медсестри першої і другої дослідних груп віддали цьому компоненту 7 місце у рейтингу, а проанкетовані
Вісник медичних і біологічних досліджень Bulletin of Medical and Biological Research
$3(9), 2021$ 
Таблиця. Загальна оцінка важливості та задоволення за складовими професійної діяльності медичних сестер

\begin{tabular}{|c|c|c|c|c|c|c|c|c|}
\hline \multirow[b]{2}{*}{$\begin{array}{c}\text { Складові (компоненти профресійної } \\
\text { діяльності }\end{array}$} & \multicolumn{4}{|c|}{ Важливість } & \multicolumn{4}{|c|}{ Задоволення } \\
\hline & $\begin{array}{l}\text { дуже } \\
\text { важ- } \\
\text { ливо, } \\
\text { \% }\end{array}$ & $\begin{array}{l}\text { важ- } \\
\text { ливо, } \\
\%\end{array}$ & $\begin{array}{l}\text { маловаж- } \\
\text { ливо, не } \\
\text { важливо, } \\
\text { \% }\end{array}$ & ранг & $\begin{array}{c}\text { пов- } \\
\text { ністю } \\
\text { задово- } \\
\text { лені, \% }\end{array}$ & $\begin{array}{c}\text { швидше } \\
\text { задово- } \\
\text { лені, \% }\end{array}$ & $\begin{array}{l}\text { не задо- } \\
\text { волені, } \\
\text { \% }\end{array}$ & ранг \\
\hline Виконувати цікаву роботу (мотиватор) & 34,7 & 42,9 & 22,4 & 7 & 16,2 & 19,6 & 64,2 & 4 \\
\hline $\begin{array}{l}\text { Самостійно ухвалювати рішення в рамках } \\
\text { своєї профресійної компетенції }\end{array}$ & 21,4 & 58,7 & 19,9 & 11 & 11,5 & 8,7 & 79,8 & 9 \\
\hline $\begin{array}{l}\text { Досягати особистих цілей під час роботи } \\
\text { (мотиватор) }\end{array}$ & 38,7 & 41,6 & 19,7 & 6 & 12,3 & 10,5 & 77,2 & 8 \\
\hline $\begin{array}{l}\text { Підтримувати добрі відносини з безпосе- } \\
\text { реднім керівником }\end{array}$ & 51,7 & 31,6 & 16,7 & 5 & 28,9 & 52,4 & 18,7 & 3 \\
\hline Підтримувати добрі відносини з колегами & 68,4 & 30,2 & 1,4 & 3 & 30,2 & 68,4 & 1,4 & 2 \\
\hline $\begin{array}{l}\text { Мати можливість профресійного росту } \\
\text { (мотиватор) }\end{array}$ & 32,3 & 21,8 & 45,9 & 8 & 12,6 & 10,9 & 76,5 & 7 \\
\hline $\begin{array}{l}\text { Мати можливість одержувати нові знання } \\
\text { й освоювати нові технології }\end{array}$ & 18,7 & 22,5 & 58,8 & 13 & 10,6 & 12,8 & 76,6 & 10 \\
\hline Мати комфортні умови праці & 79,4 & 10,9 & 9,7 & 2 & 6,7 & 12,8 & 80,5 & 11 \\
\hline $\begin{array}{l}\text { Одержувати заробітну платню відповідно } \\
\text { до обсягу та якості роботи (мотиватор) }\end{array}$ & 88,6 & 10,1 & 1,3 & 1 & 1,3 & 10,1 & 88,6 & 15 \\
\hline $\begin{array}{l}\text { Одержувати об'єктивну оцінку своєї діяль- } \\
\text { ності безпосереднім керівником }\end{array}$ & 18,9 & 12,6 & 68,5 & 12 & 16,2 & 5,8 & 78,0 & 5 \\
\hline $\begin{array}{l}\text { Брати участь і відчувати значущість своєї } \\
\text { роботи в досягненні результатів діяльності } \\
\text { ЛПЗ (мотиватор) }\end{array}$ & 26,3 & 25,7 & 48,0 & 10 & 5,8 & 10,6 & 83,6 & 12 \\
\hline Бути лідером у колективі & 15,4 & 12,6 & 72,0 & 15 & 4,7 & 5,4 & 89,9 & 13 \\
\hline Мати можливість кар'єрного росту & 30,4 & 21,7 & 47,9 & 9 & 1,6 & 5,4 & 93,0 & 16 \\
\hline Почувати себе частиною колективу & 62,9 & 30,5 & 6,6 & 4 & 32,2 & 58,4 & 9,4 & 1 \\
\hline $\begin{array}{l}\text { Бути інформованим про результати своєї } \\
\text { роботи }\end{array}$ & 16,3 & 8,7 & 75,0 & 14 & 12,4 & 18,2 & 69,4 & 6 \\
\hline $\begin{array}{l}\text { Брати участь в ухваленні рішень з проблем } \\
\text { медичного обслуговування (мотиватор) }\end{array}$ & 9,5 & 9,1 & 81,4 & 16 & 5,4 & 8,7 & 85,9 & 14 \\
\hline
\end{tabular}

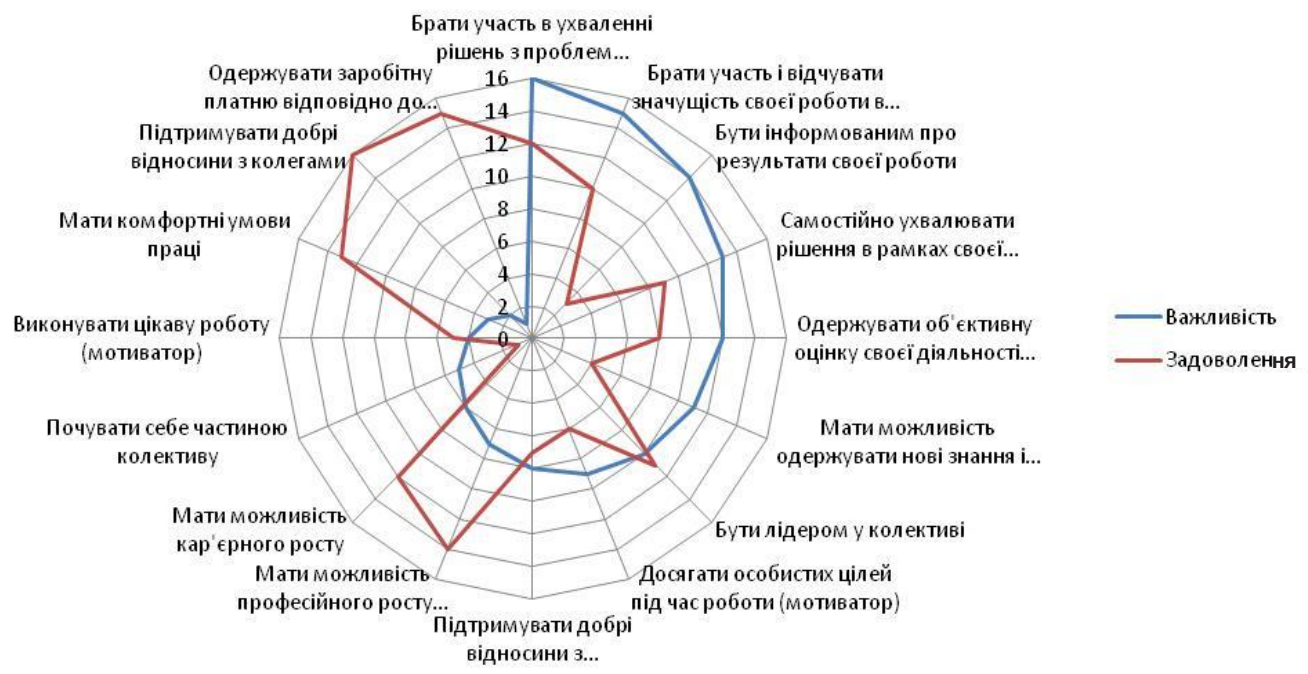

Рис. 1. Оцінка важливості та задоволення за складовими професійної діяльності медичних сестер зі стажем роботи до 5 років.

працівники третьої групи - 11 місце і, відповідно, четвертої групи - тільки 14 місце. У повсякденній практиці більшість медсестер володіє необхідними технічними даними і професійними навичками. Од- нак попри це, кожній медсестрі необхідно ретельно вивчити саму себе, особливості своєї особистості, власний стиль роботи, щоб знати, як вона впливає на хворого [6]. Для цього кожна медсестра повинна 


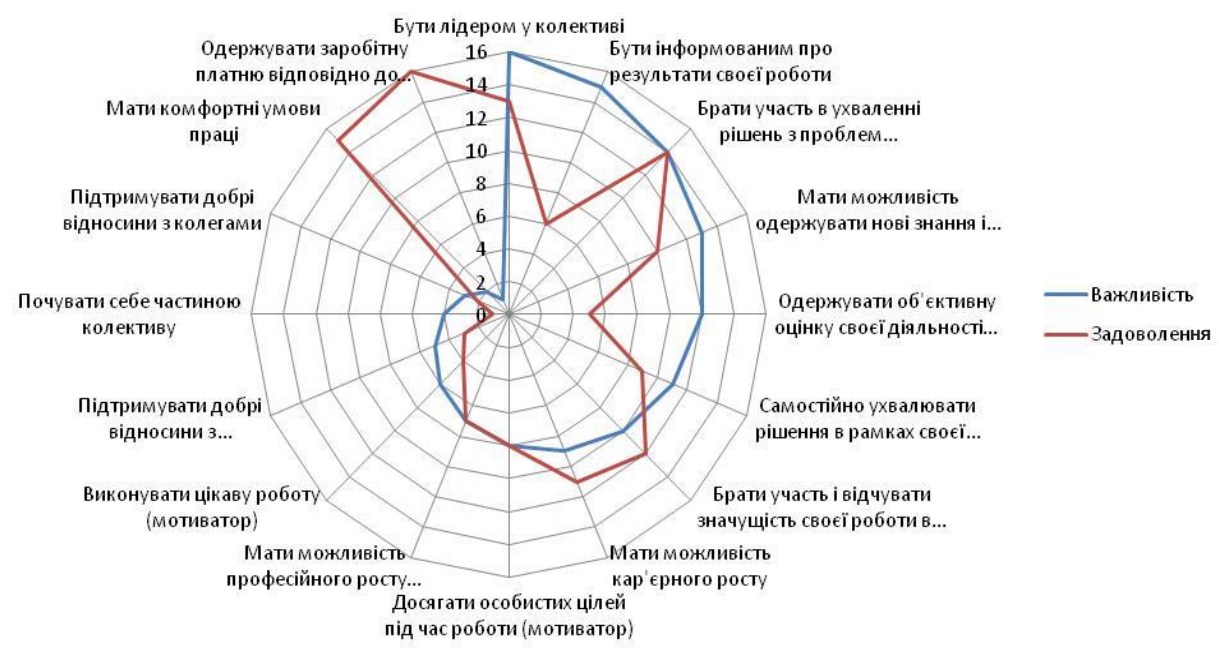

Рис. 2. Оцінка важливості та задоволення за складовими професійної діяльності медичних сестер зі стажем роботи 6-10 років.

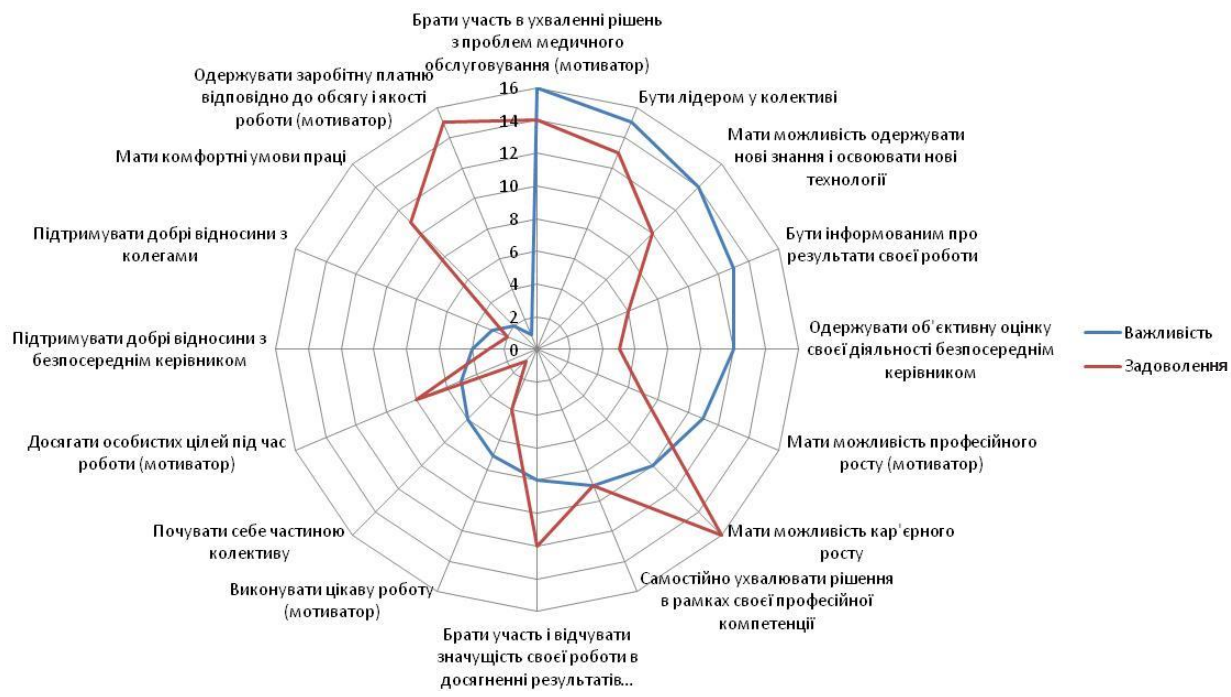

Рис. 3. Оцінка важливості та задоволення за складовими професійної діяльності медичних сестер зі стажем роботи 11-20 років.

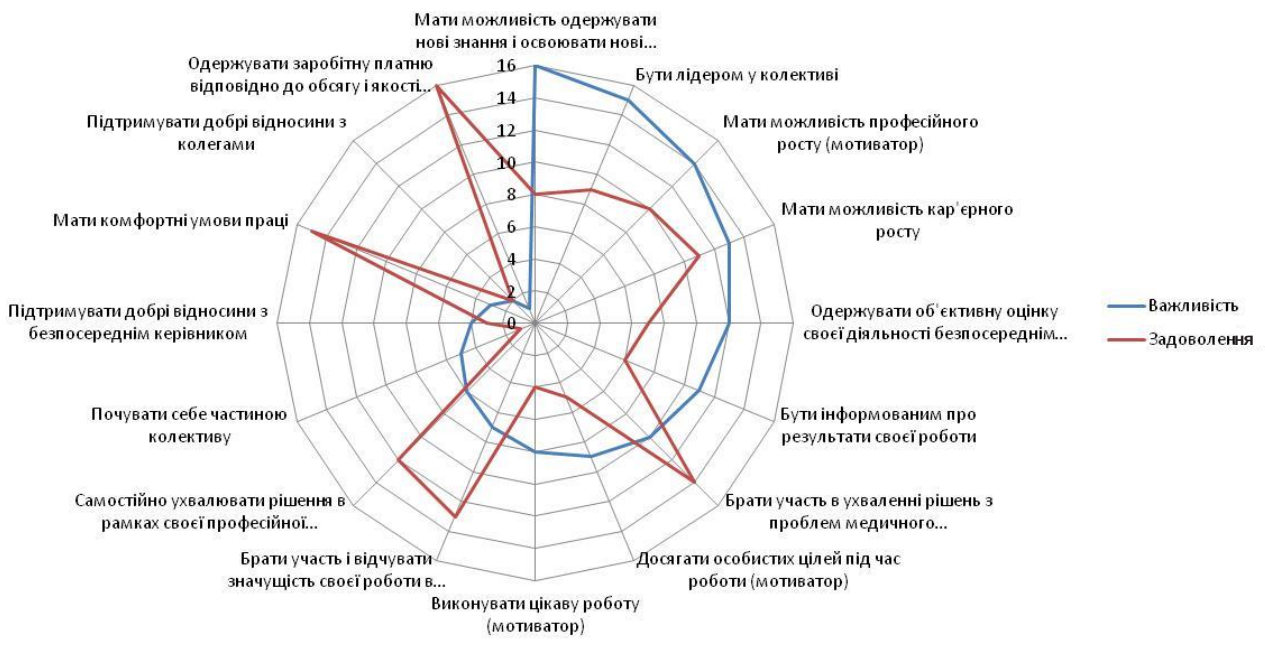

Рис. 4. Оцінка важливості та задоволення за складовими професійної діяльності медичних сестер зі стажем роботи понад 20 років. 


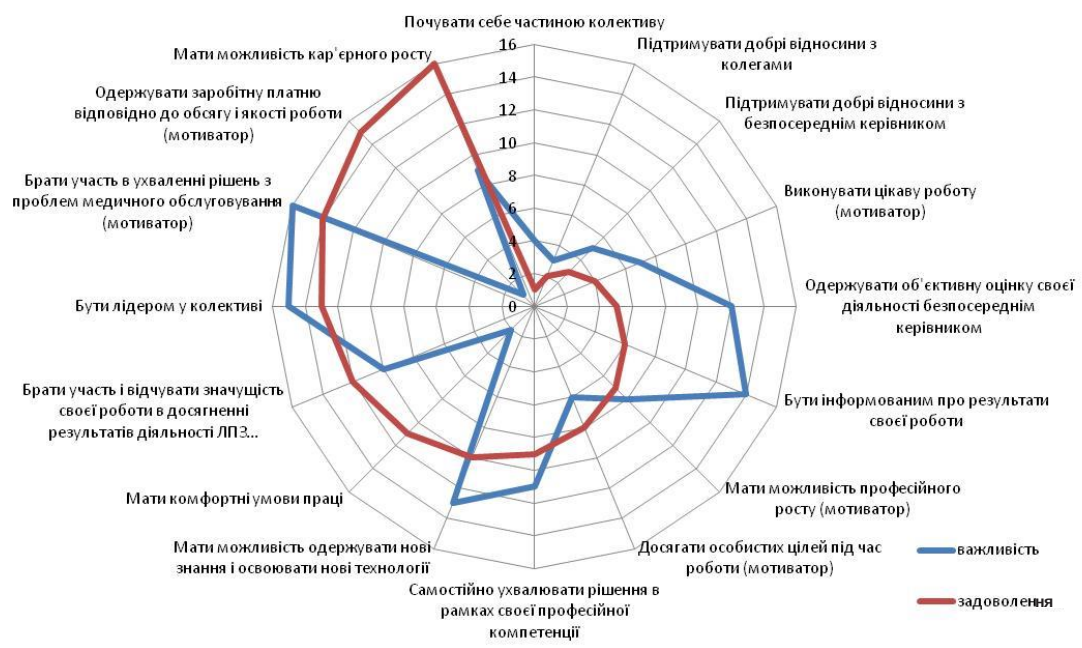

Рис. 5. Задоволення професійною діяльністю медичними сестрами за складовими компонентами професії.

пройти довгий шлях самопізнання і самовиховання. Будь-яка профресійна діяльність фрормує й усю особистість у цілому.

Серед інших важливих компонентів медичні сестри усіх дослідних груп виділяють комфортні умови праці та добрі стосунки 3 колегами. Покращення умов праці, зменшення стресових ситуацій, професійних захворювань, окрім великого соціального ефекту, впливає і на економічний результат, зокрема, підвищується продуктивність праці; зменшується плинність кадрів. Г. Г. Гогіташвілі та В. М.Лапін зазначають, що правильна організація робочого місця забезпечує збільшення продуктивності праці на $21 \%$, продумане використання музики - на 12$14 \%$, раціональне фрарбування приміщень - на $25 \%$ тощо [7].

За рейтингом важливості найменше значення для медичних сестер зі стажем роботи до 5 років має проінорормованість про результати своєї роботи. Разом з тим у другій, третій і четвертій дослідних групах на найнижчому місці рейтингу важливості стоїть лідерство у колективі. При цьому медичні сестри зі стажем роботи понад 11 років не вважають вагомим можливість одержувати нові знання й освоювати нові технології, що, ймовірно, пов'язано із набуттям професійного досвіду й зниженням мотивації до самовдосконалення. С. Д. Максименко зазначає [8], що існують дві протилежні точки зору на проблему лідерських якостей. Згідно з першою, стверджується, що людина має народитися лідером, а навчання та виховання у цьому не відіграють жодної ролі. Інша точка зору полягає в тому, що лідерські якості розвиваються, хоча для цього й потрібні певні природжені задатки. Виходячи з вищевказаного, можна припустити, що у більшості особи з лідерськими якостями не обирають профресії медичної сестри та в процесі трудової діяльності не мають можливостей ці якості розвинути.
На даний час переглядається роль середнього і молодшого медичного персоналу в бік збільшення самостійності та розширення профресійних компетенцій $[9,10]$. Варто відмітити, що за результатами проведеного дослідження в міру збільшення стажу профресійної діяльності зростала й вагомість показника щодо можливості самостійно ухвалювати рішення в рамках своєї профресійної компетенції. у більшості сучасних видів діяльності працююча людина постійно стикається 3 необхідністю брати на себе відповідальність і приймати рішення в умовах науково-технічного прогресу, коли потрібно освоювати нове технічне забезпечення, вивчати нові методи, що безперервно змінюються. Ці чинники, якщо й не зумовлюють екстремальність цієї діяльності, то все ж роблять її напруженою і вимагають спеціальної до неї адаптації.

Найбільшою мірою задоволення середнього медичного персоналу професійною діяльністю пов'язана зі здатністю себе почувати частиною колективу. Отже, задоволення працею медичної сестри тісно пов'язана 3 міжособистісними стосунками з іншими членами колективу. При цьому варто відмітити, що найбільш вагомі мотиватори (заробітна плата) мають низький рівень задоволення. Медсестри також незадоволені умовами праці, що особливо відмічається у працівників із меншим стажем роботи. Чинники, які мали низьку важливість для медсестер, в основному мали й низький рівень задоволення. Навіть при низькому рівні очікувань не спостерігалося задоволення медсестер такими чинниками як участь в ухваленні рішень із проблем медичного обслуговування (при стажі роботи понад 6 років) та лідерство у колективі (друга і третя дослідні групи). На думку О. Л. Зюкова та О. В. Мішуренка [11], це пов'язано з проблемами, які мають при працевлаштуванні та реалізації професійного потенціалу медичні сестри з вищою освітою.

Аналізуючи задоволення професійною діяль- 
ністю медичними сестрами, на перше місце вони ставлять можливість себе почувати частиною колективу, при цьому вони дали досить вагоме значення (4 місце у рейтингу) даному показнику. Мотиваційні чинники, які безпосередньо впливають на задоволення професією, розташувались на 48 місцях, разом з тим як основний мотиватор (заробітна платня) мав практично найнижчий рівень задоволення (рис. 5).

Отже, соціально-економічні та соціально-психологічні зміни в суспільстві, розвиток нових технологій в охороні здоров'я, високі вимоги до якості діяльності медичної сестри привели до необхідності вдосконалення механізмів, що забезпечують задоволення від профресійної діяльності [12]. В Україні на сьогодні, за різними даними, не вистачає понад 100 тис. медсестер. На жаль, немає жодних прогнозів як складатиметься ситуація найближчими роками, як немає й програми, спрямованої на покращення кадрової ситуації у сорері медичної допомоги, яка має передбачати впровадження складових компонентів профресії.

\section{СПИСОК ЛІТЕРАТУРИ}

1. Усова С. Н. Педагог-психолог в современном обществе: от образования к профессиональной творческой самореализации / С. Н. Усова // Вестник ТГГПУ. 2007. - № 1 (8).

2. Абульханова-Славская К. А. Стратегия жизни / К. А. Абульханова-Славская. - М. : Мысль, 1991. - 299 с.

3. Зюков О. Л. Задоволеність медичного персоналу хірургічних стаціонарів якістю медичного обслуговування онкологічних хворих / О. Л. Зюков // Медичні перспективи. - 2008. - Т. XIII, № 1. - С. 111-118.

4. Кучеренко В. 3. Концепция маркетинга медицинской услуги в добровольном медицинском страховании / В. 3. Кучеренко, В. М. Алексеева, Т. В. Скоморохова // Экономика здравоохранения. - 2003. - № 11-12. C. $40-50$.

5. Лехан В. М. Порівняльна оцінка задоволеності персоналу якістю медичного обслуговування онкологічних хворих у хірургічних стаціонарах / В. М. Лехан, О. Л. Зюков // Вісник соц. гігієни та орг. охорони здоров'я України. - 2008. - № 1. - С. 25-31.

6. Пилипчук Л. С. До проблеми етичних основ майбутніх фрахівців середньої медичної ланки / Л. С. Пилипчук // Вісник Національної академії Державної прикордонної служби України. - 2018. - № 1. - С. 1-9.

\section{вИСновки}

1. Серед основних мотиваторів трудової діяльності (виконувати цікаву роботу; досягати особистих цілей під час роботи; мати можливість профресійного росту; одержувати заробітну платню відповідно до обсягу та якості роботи; брати участь і відчувати значущість своєї роботи в досягненні результатів діяльності лікувально-профілактичного закладу; брати участь в ухваленні рішень 3 проблем медичного обслуговування) медсестри, незалежно від стажу, найважливішим вважають одержання достойної заробітної плати відповідно до обсягу та якості виконаної роботи. Серед інших важливих компонентів медичні сестри усіх дослідних груп виділяють комсоортні умови праці та добрі стосунки з колегами.

2. Найбільшою мірою задоволення середнього медичного персоналу професійною діяльністю пов'язана зі здатністю себе почувати частиною колективу, найменшою мірою - 3 оплатою праці.

7. Гогіташвілі Г. Г. Основи охорони праці : навч. посіб. - 3-є вид., стереотипне / Г. Г. Гогіташвілі, В. М. Лапін. Львів : Новий світ - 2000, 2006. - 232 с.

8. Максименко С. Д. Лідерство як функцція профресійної психологічної компетентності особистості / С. Д. Максименко // Проблеми сучасної психології. 2014. - № 24. - С. 7-16.

9. Байцим А. Ю. Роль середнього медичного персоналу в системі охорони здоров'я на сучасному етапі / А. Ю. Байцим, Д. Р. Тугаров, І. Я. Криницька // Медсестриство. - 2015. - № 4. - С. 11-14.

10. Марущак М. І. Вагомість компонентів креативності у професійній підготовці майбутніх лікарів / М. І. Марущак // Вісник Черкаського університету. Серія «Педагогічні науки». - 2019. - № 1. - С. 120-124.

11. Зюков О. Л. Аналіз задоволеності медичних сестер професійною діяльністю у лікувально-профрілактичних закладах різного профрілю / О. Л. Зюков, О. В. Мішуренко // Україна. Здоров'я нації. - 2010. № 4 (16). - C. 104-110.

12. Марущак М. І. Модернізація педагогічних умов фрормування професіоналізму майбутніх медичних сестер / М. І. Марущак, О. М. Копаниця, Н. В. Ліснянська // Вісник Черкаського університету. Серія «Педагогічні науки». - 2019. - № 2. - С. 182-185. 


\section{REFERENCES}

1. Usova SN. [Educator-psychologist in modern society: from education to professional creative self-realization]. Vestnik TGGPU. 2007;1(8). Russian.

2. Abulkhanova-Slavskaya KA. Strategy of life. [Стратегия жизни] Moscow: Mysl; 1991. Russian.

3. Zyukov OL. [Satisfaction of medical staff of surgical hospitals with the quality of medical care for cancer patients]. Medychni perspektyvy. 2008;13(1): 111-8. Ukrainian.

4. Kucherenko VZ, Alekseeva VM, Skomorokhova TV. [The concept of marketing medical services in voluntary medical insurance]. Ekonomika zdravookhraneniya. 2003;11-12: 40-50. Russian.

5. Lekhan VM, Zyukov OL. [Comparative assessment of staff satisfaction with the quality of medical care for cancer patients in surgical hospitals]. Visnyk sots hihiieny ta orh okhorony zdorovia Ukrainy. 2008;1: 25-31. Ukrainian.

6. Pylypchuk LS. [On the problem of ethical foundations of future specialists of the secondary medical level]. Visnyk Natsionalnoi akademii Derzhavnoi prykordonnoi sluzhby Ukrainy. 2018;1: 1-9. Ukrainian.

7. Gogitashvili GG, Lapin VM. Fundamentals of labor protection: Textbook. 3rd ed., Stereotypical. [Основи охо- рони праці : навч. посіб. - 3-є вид., стереотипне] Lviv: «Novyi svit-2000»; 2006. Ukrainian.

8. Maksymenko SD. [Leadership as a function of professional psychological competence of the individual]. Problemy suchasnoi psykholohii. 2014;24: 7-16. Ukrainian.

9. Baitsym AYu, Tugarov DR, Krynytska IYa. [The role of nurses in the health care system at the present stage]. Medsestrystvo. 2015;4: 11-4. Ukrainian.

10. Marushchak MI. [The importance of the components of creativity in the professional training of future doctors]. Visnyk Cherkaskoho universytetu. Serila «Pedahohichni nauky». 2019;1: 120-4. Ukrainian.

11. Zyukov OL, Mishurenko OV. [Analysis of satisfaction of nurses with professional activity in treatment and prevention facilities of different profile]. Ukraina. Zdorovia natsii. 2010;4(16): 104-10. Ukrainian.

12. Marushchak MI, Kopanytsia OM, Lisnyanska NV. [Modernization of pedagogical conditions for the formation of professionalism of future nurses]. Visnyk Cherkaskoho universytetu. Seriia «Pedahohichni nauky». 2019;2: 182-5. Ukrainian. 